\title{
TEKNIK TWO STAY TWO STRAY DALAM BIMBINGAN KELOMPOK UNTUK MENINGKATKAN WAWASAN SISWA DALAM PEMILIHAN JURUSAN DI PERGURUAN TINGGI
}

\author{
Andi Agustan Arifin, \\ Bimbingan dan Konseling, FKIP Universitas Khairun \\ email: agus_arizona@yahoo.co.id, \\ Ismail Saleh \\ SMKN 4 Ternate \\ email: daengmilebungko@gmail.com
}

\begin{abstract}
This study aimed to improve the students' knowledge in selection of majors in universities through two stay two stray technique of group guidance. The method of this study used quantitative research with the type quasi experimental design using pretestposttest control group design, data processing was calculated by statistical method. The sample of 40 students was from 20 students of IPS1 XII class and 20 students of XII IPS2 class taken by using simple random sampling, and then divided into two groups: experimental group and control group. Data collection techniques were questionnaire and observation. Data analysis techniques used descriptive analysis and t-test. The results showed that there were significant differences between the students' knowledge in selection of majors in the experimental group before (pretest) and after (posttest) giving treatment techniques two stay two stray in group counseling.
\end{abstract}

Keywords: Two stay two stray, group guidance, selection of majors

\begin{abstract}
Abstrak: Tujuan penelitian ini adalah untuk meningkatkan wawasan siswa dalam pemilihan jurusan di perguruan tinggi melalui teknik two stay two stray dalam bimbingan kelompok. Metode penelitian ini menggunakan penelitian kuantitatif dengan tipe quasi experiment menggunakan desain pretest-posttest control group design, pengolahan datanya dilakukan dengan metode statistik. Sampel sebanyak 40 siswa yang berasal dari kelas XII IPS1 sebanyak 20 siswa dan XII IPS2 sebanyak 20 siswa yang diambil menggunakan simple random sampling, kemudian dibagi ke dalam dua kelompok yaitu kelompok eksperimen dan kelompok kontrol. Teknik pengumpulan data yang digunakan adalah angket (kuesioner) dan observasi. Teknik analisis data yang digunakan dalam penelitian ini adalah analisis deskriptif dan analisis t-test atau uji t. Hasil penelitian menunjukkan bahwa terdapat perbedaan yang signifikan antara wawasan siswa dalam pemilihan jurusan pada kelompok eksperimen sebelum (pretest) dan setelah (posttest) diberikan perlakuan teknik two stay two stray dalam bimbingan kelompok.
\end{abstract}

Kata Kunci: Two stay two stray, bimbingan kelompok, pemilihan jurusan

\section{PENDAHULUAN}

Seiring dengan arus globalisasi, setiap siswa senantiasa berupaya memilih jurusan yang sesuai dengan bakat, minatnya dan sesuai dengan tuntutan lapangan kerja. Siswa harus mengoptimalkan segala potensi yang dimiliki untuk belajar dengan memilih disiplin ilmu yang mampu mendukung tercapainya cita-cita siswa. Salah satu bentuk pemilihan disiplin ilmu adalah pemilihan jurusan di SMA maupun program studi di perguruan tinggi yang mampu mendukung tercapainya cita-cita atas dasar kemampuan, bakat, minat, intelegensi dan kemampuan finansial siswa. 
Persoalan yang cukup sulit untuk diputuskan oleh kebanyakan siswa SMA, adalah terutama yang tidak banyak memiliki referensi dan mencari informasi terkait dengan pendidikan tinggi. Keputusan para siswa, terkadang dipengaruhi oleh pendapat orang tua, teman atau figur-figur yang diidolakan. Dengan hanya mendasarkan pendapat tersebut dan tanpa menelaah kemampuannya seorang siswa bisa membuat keputusan yang sangat bertolak belakang dengan kemampuannya. Sering dijumpai adanya kebingungan, keragu-raguan dan kesulitan diantara para siswa yang sedang menekuni studinya di pendidikan formal dan akan mempersiapkan dirinya untuk meniti karir di masa-masa mendatang.

Setiap siswa tentu memiliki keinginan tertentu dalam memperoleh pekerjaan atau karir setelah tamat sekolah (SMA). Ada siswa yang setelah tamat SMA akan langsung melanjutkan pendidikan di perguruan tinggi, ada yang masuk kursus, mencari kerja, atau bahkan ada yang menganggur karena tidak tahu ke mana karir yang akan dipilih sehingga terjadi problem karir. Hal ini sesuai dengan pendapat Munandir, (1996) bahwa siswa SMA ada dalam tahap kritis antara dua pilihan yang menentukan menjelang tamat: melanjutkan ke perguruan tinggi atau tidak melanjutkan, bekerja untuk mencari nafkah. Kritis juga tahapan ini karena usianya ada pada tahap karir akhir masa remaja, menjelang memasuki masa dewasa.

Bimbingan konseling merupakan bantuan yang diberikan kepada siswa dalam rangka upaya menemukan pribadi, mengenal lingkungan, dan merencanakan masa depan. Bimbingan dalam rangka merencanakan masa depan dimaksudkan agar peserta didik mampu mempertimbangkan dan mengambil keputusan tentang masa depan dirinya, baik yang menyangkut bidang pendidikan, bidang karier, maupun bidang budaya/ keluarga/masyarakat.

Bimbingan karir merupakan suatu program sistematik dimaksudkan untuk membantu individu memahami dan berbuat atas pengenalan diri, pemahaman lingkungan, pemilihan program lanjutan, mempersiapkan diri dalam menghadapi dunia kerja, memilih pekerjaan sesuai dengan bakat, minat dan kemampuan mengem-bangkan keterampilan-keterampilan untuk mengambil keputusan sehingga siswa yang bersangkutan dapat menciptakan dan mengelola perkembangan pribadi, okupasi, pendidikan dan sosial (Saleh, 2005).

Upaya peningkatan siswa dalam memahami dan menetukan pilihan karirnya dalam pemilihan jurusan dapat dilakukan dengan mengadakan kegiatan layanan bimbingan kelompok menggunakan teknik two stay two stray sebagai solusi untuk menentukan pilihan jurusan di perguruan tinggi. Teknik two stay two stray merupakan bagian dari teknikteknik pembelajaran cooperative learning. Jika pelaksanaan prosedur pembelajaran cooperative learning ini benar, akan memungkinkan untuk dapat mengaktifkan siswa sehingga dapat meningkatkan prestasi belajar siswa dan menciptakan komunikasi yang lebih baik diantara siswa. Teknik two stay two stray dapat diadopsi ke dalam model bimbingan melalui bimbingan kelompok karena dalam bimbingan kelompok siswa mampu berinteraksi dengan siswa lainnya.

Teknik two stay two stray atau sering juga disebut dengan dua tinggal dua tamu adalah salah satu model pembelajaran kelompok dimana setiap kelompoknya terdiri dari empat orang, dalam pelaksanaannya dua orang dari setiap kelompok harus bertamu ke kelompok lain serta dua orang lagi tetap tinggal di kelompoknya untuk menerima tamu dari kelompok lain (Fatirul, 2008). Teknik two stay two stray adalah merupakan cara siswa berbagi pengetahuan dan pengalaman dengan kelompok lain. Sintaknya adalah sebagai berikut: (1) kerja kelompok secara heterogen, (2) setelah selesai, dua siswa dari masing-masing kelompok bertamu ke kelompok lain, (3) dua orangyang tinggal dalam kelompok bertugas membagikan hasil kerja dan informasi ke tamu mereka dari kelompok lain, (4) tamu mohon diri dan kembali ke kelompok mereka sendiri dengan melaporkan temuan mereka dari kelompok lain, (5) kelompok mencocokkan dan membahas hasil-hasil kerja mereka (Rifaldi, 2010). Struktur two stay two stray atau dua tinggal dua tamu ini memberi kesempatan kepada kelompok untuk membagi hasil dan informasi dengan kelompok lain. Model pembelajaran teknik two stay two stray efektif untuk pembelajaran dimana kelompok siswa bekerja sama dalam setiap kelompok untuk menguasai materi yang telah diberikan, dan menjadi suatu kewajiban untuk membagi 
informasi seputar materi yang telah dikuasai kepada kelompok lain.

Dalam pelaksanaan two stay two stray dalam bimbingan kelompok di maksudkan dengan tujuan untuk mencegah timbulnya masalah pada siswa dan mengembangkan potensi siswa. Winkel, (2005) mengemukakan bahwa bimbingan kelompok di sekolah merupakan kegiatan informasi kepada sekelompok siswa untuk membantu mereka menyusun rencana dan keputusan yang tepat. Melalui informasi yang diterima siswa melalui kegiatan bimbingan kelompok menjadi wawasan bagi mereka agar dapat menyusun rencana yang tepat dan mencegah berkembangnya masalah atau kesulitan pada diri konseli (siswa). Isi kegiatan bimbingan kelompok terdiri atas penyampaian informasi yang berkenan dengan masalah pendidikan, pekerjaan, pribadi dan masalah sosial yang tidak disajikan dalam bentuk pelajaran (Nurihsan, 2005: 17).

Dalam bimbingan kelompok yang merupakan sarana untuk menunjang perkembangan optimal masing-masing siswa, yang diharapkan dapat mengambil manfaat dari pengalaman pendidikan ini bagi dirinya sendiri. Jadi dapat disimpulkan bahwa kegiatan bimbingan kelompok merupakan salah satu layanan bimbingan dan konseling yang diberikan kepada sejumlah individu dalam bentuk kelompok dengan memanfaatkan dinamika kelompok untuk membahas topik tertentu yang bertujuan untuk menunjang pemahaman, pengembangan dan pertimbangan pengambilan keputusan/tindakan individu.

Maka dari itu, peneliti akan menggunakan layanan bimbingan kelompok dengan teknik two stay two stray yang diadopsi dari pembelajaran kooperatif dalam penelitian ini. Layanan bimbingan kelompok merupakan suatu kegiatan kelompok yang dilakukan oleh sekelompok orang dengan memanfaatkan dinamika kelompok yaitu adanya interaksi saling mengeluarkan pendapat, memberikan tanggapan, saran dan sebagainya agar dapat membantu siswa mencapai perkembangan optimal.

\section{METODE}

Penelitian ini merupakan penelitian kuantitatif dengan tipe quasi experiment. Desain yang digunakan adalah "pretest - posttest control group design". Pengolahan datanya dilakukan dengan metode statistik. Populasi dalam penelitian ini adalah siswa kelas XII jurusan IPS di SMA Negeri 20 Makassar. Sampel sebanyak 40 siswa yang berasal dari kelas XII IPS1 sebanyak 20 siswa dan XII IPS2 sebanyak 20 siswa, yang diambil menggunakan simple random sampling yang kemudian dibagi ke dalam dua kelompok yaitu kelompok eksperimen dan kelompok kontrol. Teknik pengumpulan data yang digunakan adalah angket (kuesioner) dan observasi.

Variabel dalam penelitian ini yaitu teknik two stay two stray dalam bimbingan kelompok sebagai variabel bebas $(\mathrm{X})$ dan wawasan siswa dalam pemilihan jurusan di perguruan tinggi sebagai variabel terikat (Y). Teknik two stay two stray dalam bimbingan kelompok merupakan teknik dimana setiap kelompok terdiri dari 4 orang yang bekerja sama dalam setiap kelompok untuk menguasai materi yang telah diberikan, dan menjadi suatu kewajiban untuk membagi informasi seputar materi yang telah dikuasai kepada kelompok lain, dinamika dan kohesi kelompok menjadi cair sehingga siswa tidak merasa canggung atau tidak takut untuk mengemukakan pendapatnya, dan dapat memberikan pertanyaan dalam kelompoknya maupun kelompok lain. Wawasan Siswa dalam pemilihan jurusan pemahaman siswa dalam mempertimbangkan dan mempersiapkan dirinya untuk memilih jurusan tertentu yang sesuai dengan empat aspek yang mempengaruhi dalam pemilihan jurusan yaitu,bakat, minat, intelegensi, dan ekonomi.Teknik analisis data yang digunakan dalam penelitian ini adalah analisis deskriptif dan analisis t-test atau uji t.

\section{HASIL DAN PEMBAHASAN}

Hasil penelitian yang dilaksanakan di SMA Negeri 20 Makassar guna mengetahui tingkat wawasan pemilihan jurusan siswa di perguruan tinggi melalui pendekatan eksperimen dengan memberikan perlakuan berupa teknik two stay two stray dalam bimbingan kelompok. Hasil penelitian tersebut disajikan dalam bentuk analisis statistik deskriptif dan inferensial baik kelompok eksperimen maupun kelompok kontrol dan $t$-test untuk pengujian hipotesis.

Analisis statistik deskriptif dimaksudkan untuk memperoleh gambaran mengenai tingkat pemilihan jurusan siswa di perguruan tinggi sebelum (pretest) dan sesudah (posttest) diberi 
teknik two stay two stray dalam bimbingan kelompok. Berikut ini akan disajikan dalam bentuk tabel distribusi frekuensi tingkat pemilihan jurusan siswa di perguruan tinggi.

Tabel 1. Hasil analisis distribusi frekuensi pemilihan jurusan di perguruan tinggi siswa SMA Negeri 20 Makassar pretest dan posttest pemberian teknik two stay two stray dalam bimbingan kelompok

\begin{tabular}{cccccc}
\hline \multirow{2}{*}{ Interval } & \multirow{2}{*}{ Kategori } & \multicolumn{3}{c}{ Kelompok Eksperimen } \\
& & $F$ & $\mathrm{P}(\%)$ & $f$ & $\mathrm{P}(\%)$ \\
\hline $147-174$ & Sangat Tinggi & - & - & 1 & 5 \\
\hline $119-146$ & Tinggi & - & - & 13 & 65 \\
\hline $91-118$ & Sedang & 9 & 45 & 6 & 30 \\
\hline $63-90$ & Rendah & 11 & 55 & - & - \\
\hline $35-62$ & Sangat Rendah & - & - & - & - \\
\hline & Jumlah & 20 & 100 & 20 & 100 \\
\hline
\end{tabular}

Pada tabel 1 menunjukkan bahwa distribusi frekuensi tingkat pemilihan jurusan di perguruan tinggi siswa di SMA Negeri 20 Makassar sebelum diberi teknik two stay two stray dalam bimbingan kelompok, kategori rendah sebanyak 11 responden (55\%), kemudian kategori sedang sebanyak 9 responden $(45 \%)$ sedangkan pada kategori sangat rendah, tinggi, dan sangat tinggi dan tidak terdapat sama sekali responden pada kategori tersebut. Namun setelah diberikan perlakuan berupa teknik two stay two stray dalam bimbingan kelompok, maka tingkat pemilihan jurusan di perguruan tinggi pada siswa menunjukkan peningkatan, dimana pada kategori sangat tinggi sebanyak 1 responden atau (5\%), kategori tinggi sebanyak 13 responden (65\%), dan kategori sedang sebanyak 6 responden (30\%). Tingkat pemilihan jurusan siswa di perguruan tinggi pada kelompok kontrol yang dilakukan secara bersamaan terhadap kelompok eksperimen yang diperoleh berdasarkan hasil pretest yang dilaksanakan pada 14 September 2011 dan posttest pada 13 Oktober 2011 terhadap 20 siswa kelas XI IPS 2 di SMA Negeri 20 Makassar. Berikut ini disajikan data distribusi frekuensi tingkat pemilihan jurusan di perguruan tinggi siswa di SMA Negeri 20 Makassar kelompok kontrol hasil pretest dan postest yang tidak diberikan perlakuan berupa teknik two stay two stray dalam bimbingan kelompok.

Tabel 2. Hasil analisis distribusi frekuensi pemilihan jurusan di perguruan tinggi siswa SMA Negeri 20 Makassar kelompok kontrol hasil pretest dan posttest

\begin{tabular}{cccccc}
\hline \multirow{2}{*}{ Interval } & \multirow{2}{*}{ Kategori } & \multicolumn{4}{c}{ Kelompok Kontrol } \\
& & $f$ & $\mathrm{P}(\%)$ & $f$ & $\mathrm{P}(\%)$ \\
\hline $147-174$ & Sangat Tinggi & - & - & - & - \\
\hline $119-146$ & Tinggi & - & - & - & - \\
\hline $91-118$ & Sedang & 13 & 65 & 16 & 80 \\
\hline $63-90$ & Rendah & 7 & 35 & 4 & 20 \\
\hline $35-62$ & Sangat Rendah & - & - & - & - \\
\hline & Jumlah & 20 & 100 & 20 & 100 \\
\hline
\end{tabular}

Pada tabel 2 di atas menunjukkan bahwa distribusi frekuensi tingkat pemilihan jurusan di perguruan tinggi siswa untuk kelompok kontrol saat pretest secara umum dalam kategori sedang sebanyak 13 responden atau $65 \%$, 
kategori rendah sebanyak 7 responden atau 35\%. Namun saat posttest kondisi pada kategori sedang menunjukkan sedikit peningkatan yaitu sebanyak 3 responden sehingga meningkat menjadi 16 responden atau $80 \%$. Dimana kategori rendah sebanyak 4 responden atau $20 \%$ mengalami penurunan pada kategori rendah sebanyak 3 responden sehingga menurun menjadi 3 responden atau $15 \%$. Namun saat posttest kondisi tersebut tidak menunjukkan perubahan yang berarti, dimana kategori sedang sebanyak 17 responden atau $85 \%$ dan kategori rendah sebanyak 3 responden atau $15 \%$.

Tabel 3. Hasil analisis distribusi nilai rata-rata pada kelompok eksperimen dan kontrol pada tahap pretest dan posttest pemilihan jurusan di perguruan tinggi siswa SMA Negeri 20 Makassar.

\begin{tabular}{ccccc}
\hline Jenis Data & Kelompok & Mean & Interval & Klasifikasi \\
\hline \multirow{2}{*}{ Pretest } & Eksperimen & 86.8 & $63-90$ & Rendah \\
\cline { 2 - 5 } & Kontrol & 92.65 & $91-118$ & Sedang \\
\hline \multirow{2}{*}{ Posttest } & Eksperimen & 124.95 & $119-146$ & Tinggi \\
\cline { 2 - 5 } & Kontrol & 94.70 & $91-118$ & Sedang \\
\hline
\end{tabular}

Dari tabel 3, dapat dilihat bahwa rata-rata skor pretest pada variabel tingkat wawasan siswa dalam pemilihan jurusan di perguruan tinggi pada kelompok eksperimen sebesar 86,8 berada pada kategori rendah dan kelompok kontrol pada pretest sebesar 92,65 berada pada kategori sedang. Hal ini berarti kedua kelompok memiliki wawasan tentang pemilihan jurusan diperguruan tinggi masih kurang. Setelah pemberian perlakuan kepada kelompok eksperimen, kemudian peneliti mengukur tingkat wawasan pemilihan jurusan diperguruan tinggi pada kelompok eksperimen dan kelompok kontrol. Dari hasil analisis tersebut dapat dilihat bahwa rata-rata pada kedua kelompok tidaklah sama, kelompok eksperimen tingkat wawasan pemilihan jurusan diperguruan tinggi tergolong dalam kategori tinggi, sedangkan kelompok kontrol berada pada kategori sedang.

Pengujian hipotesis pertama yang diajukan dalam penelitian ialah " terdapat perbedaan yang signifikan antara wawasan siswa dalam pemilihan jurusan di perguruan tinggi pada kelompok eksperimen sebelum (pretest) dan setelah (posttest) diberikan perlakuan teknik two stay two stray dalam bimbingan kelompok". Pengujian hipotesis ini dilakukan dengan uji t atau $t$-test dengan menggunakan SPSS versi 17.0. Berdasarkan hal tersebut didapatkan hasil perhitungan seperti yang terangkum pada tabel berikut:

Tabel 4. Hasil analisis uji t-test perbedaan wawasan siswa dalam pemilihan jurusan pada pretest dan posttest kelompok eksperimen

\begin{tabular}{|c|c|c|c|c|c|c|}
\hline \multicolumn{7}{|c|}{$\begin{array}{l}\text { Paired Sample Test } \\
\text { Paired Differences }\end{array}$} \\
\hline & & Mean & $\begin{array}{c}\text { Std. } \\
\text { Deviation }\end{array}$ & $\mathrm{T}$ & Df & Sig.(2-tailed) \\
\hline $\begin{array}{c}\text { wawasan siswa } \\
\text { dalam pemilihan } \\
\text { jurusan }\end{array}$ & $\begin{array}{c}\text { Pre-post } \\
\text { Eksperimen }\end{array}$ & 38,15 & 11,19 & 11,579 & 19 & ,000 \\
\hline
\end{tabular}

Berdasarkan tabel 4 di atas, terlihat bahwa diperoleh nilai t-test=11, 579 dengan $\mathrm{df}=19$. Harga $t_{\text {tabel }}$ pada $\mathrm{t}_{0,05}=2,093$ dengan nilai signifikan $(\mathrm{P})=0,000<\alpha=0,05$. Angka probabilitas Asmyp. Sig(2-tailed) wawasan siswa dalam pemilihan jurusan pada kelompok eksperimen sebesar 0,000 , atau probabilitas dibawah alpha $0,05(0,000<0,05)$. Dari hasil tersebut maka Ho ditolak dan $\mathrm{H}_{1}$ diterima. Dengan demikian maka hipotesis pertama yang diuji dalam penelitian ini dapat diterima, yaitu “ terdapat perbedaan yang signifikan antara wawasan siswa dalam pemilihan jurusan pada kelompok eksperimen pretest dan posttest diberikan perlakuan teknik two stay two stray dalam bimbingan kelompok". 
Hipotesis kedua yang diajukan dalam penelitian ialah "Tidak terdapat perbedaan antara wawasan siswa dalam pemilihan jurusan pada kelompok kontrol pretest dan posttest diberikan perlakuan teknik two stay two stray dalam bimbingan kelompok". Pengujian hipotesis ini dilakukan dengan uji t atau $t$ test. Berdasarkan hal tersebut didapatkan hasil perhitungan seperti yang terangkum pada tabel berikut ini:

Tabel 5. Hasil analisis uji t-test perbedaan wawasan siswa dalam pemilihan jurusan pada pretest dan posttest kelompok control

\begin{tabular}{|c|c|c|c|c|c|c|}
\hline & & \multicolumn{2}{|c|}{$\begin{array}{l}\text { Paired Sample Test } \\
\text { Paired Differences }\end{array}$} & \multirow[b]{2}{*}{$\mathrm{T}$} & \multirow[b]{2}{*}{ Df } & \multirow[b]{2}{*}{ Sig.(2-tailed) } \\
\hline & & Mean & $\begin{array}{c}\text { Std. } \\
\text { Deviation }\end{array}$ & & & \\
\hline $\begin{array}{c}\text { wawasan siswa } \\
\text { dalam pemilihan } \\
\text { jurusan }\end{array}$ & $\begin{array}{l}\text { Pre-post } \\
\text { Kontrol }\end{array}$ & 2,05 & ,59 & 1,96 & 19 & ,044 \\
\hline
\end{tabular}

Berdasarkan tabel 5, terlihat bahwa nilai $\mathrm{t}$-test $=1,96$ dengan $\mathrm{df}=19$. Harga $\mathrm{t}_{\text {tabel }}$ pada $\mathrm{t}_{0,05}$ $=2,093$ dengan nilai signifikan $(\mathrm{P})=0,000>\alpha=$ 0,05. Angka probabilitas Asmyp Sig.(2-tailed) wawasan siswa dalam pemilihan jurusan pada kelompok kontrol sebesar 0,044 atau probabilitas di atas alpha $0,05 \quad(0,044>0,05)$. Dari hasil tersebut maka $\mathrm{Ho}$ diterima dan $\mathrm{H}_{1}$ ditolak. Dengan demikian maka hipotesis kedua yang diuji dalam penelitian ini dapat diterima, yaitu " Tidak terdapat perbedaan yang signifikan antara wawasan siswa dalam pemilihan jurusan pada kelompok kontrol sebelum (pretest) dan setelah (posttest) diberikan perlakuan teknik two stay two stray dalam bimbingan kelompok".

Berdasarkan hasil posttest pada kelompok eksperimen diperoleh perubahan pada siswa yang di awal memiliki wawasan dalam pemilihan jurusan di perguruan tinggi sedang dan rendah kearah yang lebih tinggi. Perubahan tersebut diasumsikan karena disebabkan oleh perlakuan yang diberikan yaitu teknik two stay two stray dalam bimbingan kelompok. Hasil temuan lainnya adalah bahwa pada kelompok kontrol tidak tidak mengalami peningkatan yang signifikan antara hasil pretest dan posttest. Ratarata pada variabel memiliki wawasan dalam pemilihan jurusan di perguruan tinggi sebesar 92.65 pretest menjadi 94.70 posttest dengan kategori tetap sama yaitu dengan kategori tetap sedang.

Berdasarkan hasil analisis data tersebut, maka dapat diartikan bahwa wawasan tentang pemilihan jurusan pada perguruan tinggi bagi siswa meningkat setelah diberikan perlakuan berupa layanan bimbingan kelompok melalui teknik two stay two stray. Peningkatan ini diasumsikan karena dalam layanan bimbingan kelompok memungkinkan siswa-siswi untuk bisa berpartisipasi aktif dan antusias mengikuti diskusi pembahasan topik, saling bertukar pendapat dan pengalaman sehingga siswa dalam kegiatan layanan ini banyak memperoleh hal baru terutama informasi yang berkaitan dengan jurusan pada perguruan tinggi. Hal ini sesuai dengan pendapat Prayitno, (1995:68) bahwa dalam bimbingan kelompok melalui dinamika kelompok peserta mampu mendapatkan wawasan, pengetahuan, keterampilan, nilai-nilai dan sikap yang berperan sebagai pendukung dalam memahami dan memecahkan masalah, sehingga setiap anggota kelompok dapat mengembangkan diri dan mendapatkan keuntungan dari kegiatan layanan bimbingan kelompok tersebut.

Dalam penerapan teknik two stay two stray dalam bimbingan kelompok siswa yang bingung dalam pemilihan jurusan di perguruan tinggi akan mampu menentukan jurusan yang ada di perguruan tinggi dengan memperoleh berbagai informasi jurusan-jurusan di perguruan tinggi. Selain memperoleh pengetahuan tentang pemilihan jurusan serta dunia karir, siswa juga dapat mengetahui dan memahami pentingnya kebersamaan dan makna dari sebuah kelompok.

Bimbingan kelompok sangat tepat bagi kelompok remaja karena memberikan kesempatan untuk menyampaikan gagasan, 
perasaan, permasalahan, melepas keragu-raguan diri, dan pada kenyataanya mereka akan senang berbagi pengalaman dan keluhankeluhan pada teman sebayanya. Nurihsan (2006: 23) mengungkapkan bahwa bimbingan kelompok merupakan bantuan terhadap individu yang dilaksanakan dalam situasi kelompok, bimbingan kelompok berupa penyampaian informasi atau aktivitas kelompok membahas masalah-masalah pendidikan, pekerjaan, pribadi dan sosial.

Pelaksanaan teknik two stay two stray dalam bimbingan kelompok akan membuat siswa merasa lebih mudah membicarakan topik/persoalan-persoalan yang mereka hadapi kepada kelompok sebayanya, di mana mereka akan dapat leluasa dalam bergaul dan saling terbuka dalam membahas persoalan melalui bentuk diskusi yang hangat dan akrab, sehingga mereka akan dapat saling memberikan dukungan, motivasi dan juga saling bertukar pikiran, pendapat dan pengalaman yang nantinya akan bermanfaat bagi mereka sendiri dalam mengembangkan dan meningkatkan wawasan dalam pemilihan jurusan di perguruan tinggi.

Uraian pembuktian hipotesis ini mengisyaratkan bahwa keberhasilan teknik two stay two stray dalam bimbingan kelompok ditentukan oleh beberapa faktor diantaranya faktor internal dan faktor ekternal. Faktor internal yaitu faktor yang berkaitan dengan diri siswa,diantaranya adalah kemampuan, minat, motivasi, keaktifan belajar dan lain-lain. Sedangkan faktor eksternal adalah faktor dari luar diri siswa diantaranya model pembelajaran yang diadopsi ke dalam layanan bimbingan konseling sehingga kegiatan tersebut terdapat bentuk interaksi dan dinamika kelompok yang akan memberikan kehidupan dan warna dalam kelompok tersebut. Menurut Mungin dalam (Kapandra, dkk. 2014: 10) menyatakan bahwa bimbingan kelompok merupakan suatu kegiatan kelompok dimana pimpinan kelompok menyediakan informasi-informasi dan mengarahkan diskusi agar anggota kelompok menjadi lebih sosial atau untuk membantu anggota-anggota kelompok untuk mencapai tujuan-tujuan bersama.

Hal itu menjelaskan bahwa kegiatan bimbingan kelompok akan berhasil, ketika ada interaksi dan dinamika yang terjadi di dalamnya atau sebaliknya bimbingan kelompok tidak akan berhasil apabila tidak ada interaksi dan dinamika yang dapat menghidupkan kelompok tersebut. Teknik two stay two stray dalam bimbingan kelompok tersebut di samping sebagai sebuah bentuk atau upaya bantuan, juga merupakan tempat atau wadah yang efektif yang bertujuan antara lain yaitu untuk mengembangkan diri siswa, termasuk di dalamnya ada pemahaman terhadap diri sendiri dan orang lain, sikap menerima diri secara wajar, mengerti akan keberadaaan orang lain dan menumbuhkan perasaan dan sikap kepedulian dan kepekaannya terhadap orang lain atau lingkungan yang semuanya itu merupakan salah satu dari bentuk/indikator wawasan pemahaman siswa dalam pemilihan jurusan diperguruan tinggi yang perlu diwujudkan dan dikembangkan oleh siswa.

Model pembelajaran teknik two stay two stray efektif untuk pembelajaran, dimana kelompok siswa bekerja sama dalam setiap kelompok untuk menguasai materi yang telah diberikan, dan menjadi suatu kewajiban untuk membagi informasi seputar materi yang telah dikuasai kepada kelompok lain (Lie, 2002). Keefektifan teknik tersebut didasari oleh aktivitas anggota kelompok dalam melakukan kerja kelompok yang dapat dilihat dari beberapa aspek, yakni:

a. Mengambil inisiatif, antara lain mengajukan pendapat baru, merumuskan dan memberi pengertia baru terhadap masalah sehingga menjadi lebih jelas serta mengusulkan pemecahan masalah.

b. Mencari informasi, antara lain meminta penjelasan terhadap saran yang diajukan, meminta tambahan informasi atau fakta dan data.

c. Mengumpulkan pendapat, antara lain menanyakan ekspresi perasaan anggota serta usul atau ide para anggota terhadap suatu masalah.

d. Memberi informasi, antara lain menyajikan fakta dan memberikan kesimpulan dengan ilustrasi pengalamannya.

e. Mencari pendapat, antara lain menanyakan pendapat atau keyakinan anggota tentang suatu saran, terutama yang terkait dengan nilai-nilai.

f. Mengolah informasi, yaitu menjelaskan, memberi contoh, menafsirkan dan menggambarkan akibat yang dapat terjadi apabila saran dilaksanakan

g. Menyimpulkan, antara lain menyimpulkan pendapat atau saran-saran yang saling 
berhubungan dan mengulang saran tersebut setelah kelompok selesai mendiskusikannya.

Selain itu, aspek keberhasilan tersebut di atas, aspek psikolgis kelompok juga dapat memberikan dampak keberhasilan dalam kegiatan kelompok dalam pelaksanaan two stay two stray. Aspek dan peristiwa psikologis dalam kelompok terjadi dalam proses sebuah hubungan yang di dalamnya mengandung: 1) Komunikasi, 2) kerjasama, 3) umpan balik, 4) Saling percaya, 5) Keterbukaan, 6) Realisasi diri dan 7) Saling ketergantungan. Peristiwa psikologis tersebut akan dapat berjalan baik jika berlangsung dalam sebuah kelompok tanpa mangalami hambatan di antara individu yang terlibat. Apabila hal tersebut terjadi, akan menghasilkan sebuah kelompok yang sangat efektif untuk berlangsungnya sebuah bentuk layanan bimbingan kelompok.

Para ahli dalam bidang bimbingan konseling kelompok menekankan penyajian informasi sebagai komponen yang ditonjolkan dalam bimbingan kelompok agar para siswa membekali diri dengan pengetahuan dan pemahaman yang membantu mereka untuk mengatur kehidupannya sendiri, untuk melihat dengan lebih jelas segala unsur permasalahan yang dihadapi dalam menentukan program studi dan merencanakan masa depan, serta untuk belajar mengenai prosedur yang tepat dalam mengambil keputusan berdampak serba penting dalam hidupnya. (Hartinah, 2009:160).

Maka dari itu, bimbingan kelompok di sekolah merupakan kegiatan pemberian informasi kepada sekelompok siswa untuk membantu mereka menyusun rencana dan keputusan yang tepat. Pemahaman tentang berbagai masalah harus diketahui secara dini agara dapat memberikan bentuk bimbingan secara tepat dan benar. Oleh karena itu, agar dapat memberikan bentuk bimbingan kelompok perlu segera diberikan pada siswa. Layanan bimbingan kelompok yang memungkinkan sejumlah peserta didik secara bersama-sama, melalui dinamika kelompok, memperoleh berbagai bahan dari narasumber tertentu, terutama dari konselor dan atau membahas secara bersama-sama pokok bahasan tertentu yang berguna untuk mennjang pemahaman dalam kehidupan sehari-hari. Untuk mengembangkan diri scecara optimal, baik sebagai individu maupun sebagai siswa di sekolah, perlu dipahami serta dilakukan agar masalah siswa dapat diketahui secara dini.

\section{SIMPULAN DAN SARAN}

Berdasarkan hasil penelitian yang dilakukan, maka dapat disimpulkan bahwa teknik two stay two stray dalam bimbingan kelompok efektif untuk meningkatkan wawasan siswa dalam pemilihan tinggi siswa di SMA Negeri 20 Makassar sebelum diberi perlakuan berupa teknik Two Stay Two Stray baik kelompok eksperimen maupun kelompok kontrol pada umumnya berada pada kategori rendah dan sedang, akan tetapi, setelah diberi perlakuan menunjukkan perubahan dari tingkat pemilihan jurusan dari rendah menjadi kategori tinggi, sedangkan bagi siswa yang tidak diberi perlakuan tidak menunjukkan perubahan berarti atau tetap dalam kategori sedang.

Berdasarkan kesimpulan dari hasil peneliti kemukakan, maka peneliti memberikan saran kepada konselor sekolah hendaknya dapat melaksanakan teknik two stay two stray secara terprogram untuk membahas topik tentang wawasan siswa dalam pemilihan jurusan di perguruan tinggi dan diharapkan konselor sekolah lebih kreatif dan inovatif dalam melaksanakan layanan bimbingan kelompok di sekolah. Kepada kepala sekolah disarankan untuk dapat mengalokasikan/menyediakan jam khusus (sekurang-kurangnya 2 jam pelajaran) untuk pelaksanaan bimbingan kelompok setiap minggu setiap kelasnya. Kepada siswa, hendaknya berusaha secara optimal memanfaatkan layanan bimbingan dan konseling khususnya layanan bimbingan kelompok agar dapat memperoleh berbagai informasi.

\section{DAFTAR RUJUKAN}

Fatirul,A. 2008. Cooperative Learning. (Online),(http://trimanjuniarso.files.word press.com). Diakses 5 Mei 2015.

Hartinah, S. 2009. Konsep Dasar Bimbingan Kelompok. Bandung: Refika Aditama.

Hallen, A. 2005. Bimbingan dan Konseling. Ciputat: PT. Ciputat Press.

Kapandra, H,dkk. 2014. Mengefektifkan Gaya Belajar Auditory Melalui Bimbingan Kelompok Pada Siswa Kelas XI IPA II 
di SMA. Jurnal Konseling Komprehensif. 01 (01): 9-17

Lie, Anita. 2002. Mempraktikkan Cooperative Learning di Ruang-Ruang Kelas. Jakarta: Gasindo.

Munandir. 1996. Program Bimbingan Karir di Sekolah. Jakarta: Depdikbud.

Nurihsan, Achmad Juntika. 2005. Strategi Layanan Bimbingan dan Konseling. Bandung: Refika Aditama.

2006. Bimbingan dan Konseling dalam Berbagai Latar Kehidupan. Bandung: Refika Aditama.
Rifaldi, A.M. 2010. Penerapan Pembelajaran Kooperatif Model Two Stay Two Stray (TSTS) Untuk Meningkatkan Aspek Kognitif dan Aspek Afektif Siswa Kelas X.5 SMA Negeri 02 Junrejo, Kota Batu. Skripsi: Malang

Saleh, M. Abubakar. 2005. Bimbingan dan Kematangan Karir. Makassar: Jurusan PPB FIP UNM

Sugiyono, 2010. Metode Penelitian Kuantitatif, Kulitatif, dan R\&D. Bandung: Alfabeta.

Winkel \& Hastuti, Sri. 2005. Bimbingan dan Konseling di Institusi Pendidikan. Yogyakarta: Media Abadi. 